\title{
Seed-Coat microsculpturing of some Cardamine (Brassicaceae) taxa and its systematic importance
}

Emrah ŞİRIN *1, Kuddisi ERTUĞRUL ${ }^{1}$

ORCID: 0000-0003-3408; 0000-0002-6463-2918

${ }^{1}$ Faculty of Science, Selçuk University, 42031 Konya, Turkey

\begin{abstract}
The seed exomorphic characteristics of four taxa (Cardamine graeca, C. impatiens subsp. impatiens, $C$. raphanifolia and $C$. uliginosa) belonging to Cardamine were investigated with scanning electron microscopy (SEM). This study presents exomorphic characteristics, including seed colour, shape, winged, measures, seed coat pattern. Four coat patterns were observed; regularly reticulate, irregularly-reticulate, blister and tuberculate-reticulate, and two shapes were distinguished; broadly oblong and oblong. The results showed that the morphological characteristics of seed could contribute as criteria to distinguish taxa. This is the first study in which the seed surface of any Cardamine taxa growing in Turkey is studied with SEM.
\end{abstract}

Key words: classification, Cruciferae, micromorphology, seed surface ornamentation, SEM, taxonomy

Bazı Cardamine (Brassicaceae) taksonlarının tohum yüzey mikro şekilleri ve taksonomik önemi

\section{Özet}

Cardamine cinsine ait olan dört taksonun (Cardamine graeca, C. impatiens subsp. impatiens, C. raphanifolia and C. uliginosa) tohum dış morfolojileri, taramalı electron mikroskobu (SEM) ile incelendi. Bu çalışma tohum rengi, şekli, kanatı, ölçüsü ve tohum yüzey modelini içeren dış morfolojik karakterleri sunmaktadır. Dört tohum yüzeyi modeli; düzenli-retikulat, düzensiz-retikulat, kabarcıklı ve tüberküllü-retikulat gözlendi ve iki tane de tohum şekli; geniş oblong ve oblong tespit edildi. Sonuçlar tohumların morfolojik karakterlerinin taksonların ayrımına katkı sağlayabileceğini göstermiştir. Bu çalışma Türkiye'de yetişen herhangi bir Cardamine taksonunun tohum yüzeyinin SEM ile incelendiği ilk çalışmadır.

Anahtar kelimeler: sınıflandırma, Cruciferae, mikromorfoloji, SEM, taksonomi, tohum yüzeyi modellemesi

\section{Introduction}

Turkey is one of the richest countries in the world in terms of Brassicaceae with 571 species. At the first volume of the Flora of Turkey, the number of Brassicaceae genus and species was indicated to be 86 and 464 , respectively [1]. These numbers have increased to 88 genus and 526 species in the 10th volume [2] and to 91 genus and 555 species in the 11th volume of Flora of Turkey [3]. In the 2nd supplement of Flora of Turkey, the total number of the species increased to 538 with the addition of one genus, 28 species, 15 subspecies, and two varieties [4].

Cardamine L. is the third largest genera of Brassicaceae family with approximately 200 species spreading all over the world except Antarctica [5,6]. Taxonomic revision studies have been carried out on Cardamine species in different parts of the world [7, 8, 9]. In Turkey Cardamine has represented with 14 taxa and none of them is not endemic [10]. All studied taxa, except C. raphanifolia (Euro-Siberian element), are widely distributed [1].

Seed surfaces, color, and size are valuable characteristics for distinguishing taxa in Brassicaceae [11, 12, 13, 14]. The four taxa studied were closely positioned in the identification key of Flora of Turkey [1]. Therefore the main

\footnotetext{
* Corresponding author / Haberleşmeden sorumlu yazar: Tel.: +903322231881; Fax.: +903322231881; E-mail: emrahsirin@ selcuk.edu.tr

(C) Copyright 2021 by Biological Diversity and Conservation $\quad$ Received: 4.7.2020; Published: 15.12.2020 BioDiCon. 899-0320
} 
objective of this study is to evaluate the taxonomic significance of the seed coat pattern as seen by SEM in some taxa of the Cardamine and to contribute to the distinction of species.

\section{Materials and methods}

The study material comprised samples of ripe seeds from four taxa belonging to Cardamine collected from natural habitats in Turkey between 2015 and 2016. The samples were stored at Konya Selçuk University Faculty of Science Herbarium (KNYA). The locations and collector registration numbers of the taxa studied are provided in Table 1 ; the seed micromorphology characteristics are provided in Table 2. Twenty seeds from each taxon were examined in our study.

Samples examined in our analyses using scanning electron microscopy (SEM) were first passed through a series of 70, 80, 96, and $100 \%$ alcohol for 20 min each. The surfaces were then observed and photographed with the ZEISS EVO LS-10 scanning electron microscope at 30x, 1000x, and 2000x magnification in high vacuum mode.

The seed micromorphology terminology used was according to [13, 15, 16].

Table 1. Localities of the studied taxa

\begin{tabular}{|c|c|}
\hline TAXA & LOCALITY \\
\hline Cardamine graeca $\mathrm{L}$. & $\begin{array}{l}\text { C4 Karaman: Sarıveliler, Çukurbağ Köyü, kurumuş dere kenarı, } 800 \text { m, 30.06.2015, } \\
\text { E. Şirin } 573 \text { \& M. Şirin (KNYA) }\end{array}$ \\
\hline $\begin{array}{l}\text { C. impatiens L. subsp. } \\
\text { impatiens }\end{array}$ & $\begin{array}{l}\text { A3 Bolu: Yedigöller Milli Parkı, Fagus orientalis ormanı, } 1500 \text { m, 04.05.2016, E. } \\
\text { Şirin } 615 \text { \& M. Şirin (KNYA) }\end{array}$ \\
\hline C. raphanifolia Pourr. & $\begin{array}{l}\text { A8 Erzurum: Aziziye, Ahırcık Yaylası, dere kenarı, } 2400 \text { m, 13.08.2015, E. Şirin } \\
538 \& \text { M. Şirin (KNYA) }\end{array}$ \\
\hline C. uliginosa M. Bieb. & $\begin{array}{l}\text { A9 Ardahan: Damal'dan Posof'a 20. km, çayırlık alan, } 2450 \text { m, 10.06.2016, E. Şirin } \\
639 \& \text { M. Sirin (KNYA) }\end{array}$ \\
\hline
\end{tabular}

\section{Results}

The micrographs from the seeds of the four taxa studied are shown in Fig. 1 and the macro- and micromorphological properties of the seeds are provided in Table 2.

C. graeca: Seed dark brown to black, oblong, winged, glabrous, 4.61-4.82 x 1.91-2.42 mm and the seed coat pattern is regularly reticulate (Table 2 , Fig. 1).

C. impatiens: Seed brown, broadly oblong, wingless, glabrous, $1.11-1.02 \times 0.71-0.83 \mathrm{~mm}$ and the seed coat pattern is irregularly reticulate (Table 2, Fig. 1).

C. raphanifolia: Seed brown, oblong, wingless, glabrous, $0.82-1.12 \times 0.42-0.71 \mathrm{~mm}$ and the seed coat pattern is blister (Table 2, Fig. 1).

C. uliginosa: Seed dark brown to black, broadly oblong, winged, glabrous, $4.52-4.92 \times 2.06-3.28 \mathrm{~mm}$ and the seed coat pattern is tuberculate reticulate (Table 2, Fig. 1).

\section{Conclusions and discussion}

Seed surface patterns provide valuable characters for the identification of taxa in selected groups of Brassicaceae $[11,12,13,17]$. In the previous study, seed surface patterns of the $C$. graeca and $C$. impatiens were evaluated as smooth [11, Table 3]. However, it would be more appropriate to evauate C.graeca as regularly reticulate and $C$. impatiens as irregularly reticulate since the evaluation was not made using a SEM. Other seed surface patterns have been defined on Cardamine flexuosa (undulate) and C. hirsuta (microreticulate) [16]. Blister, which is the surface model of $C$. raphanifolia, was also observed in Brassica nigra and B. oleracea, which are not related to Cardamine [17].

In this study, a broadly oblong shape was observed in most of the seeds. A similar result was found in Matthiola tricuspidata, which is not related to Cardamine [19]. Although [11] interpreted the seed shapes of $C$. graeca as orbicular to oval and of $C$. impatiens as oval, according to Stearn's [15] system, it is more appropriate to interpret the seed shapes of $C$. graeca as oblong and $C$. impatiens as broadly oblong.

C. impatiens and $C$. raphanifolia differed from the others with wingless seed. Because all of the studied taxa had wingless seed, this character cannot be considered distinctive. Bunias erucago, Euclidium syriacum, Hymenophysa pubescens and Neslia paniculata are some other species in the same family with wingless seed structures [11]. $C$. raphanifolia had relatively smaller seeds compared to the others.

Because all of the studied taxa had dark brown to black seed color, this cannot be considered as a distinctive character. [20] observed a similar seed color in Lepidium taxa, which are not related with the Cardamine. 
All of the taxa had a glabrous seed surface. [21] reported a similar situation in Brassica juncea, B. tournefortii, Eruca sativa, Raphanus sativus, Cakile arabica, and Sisymbrium irio, which are not related to Cardamine.

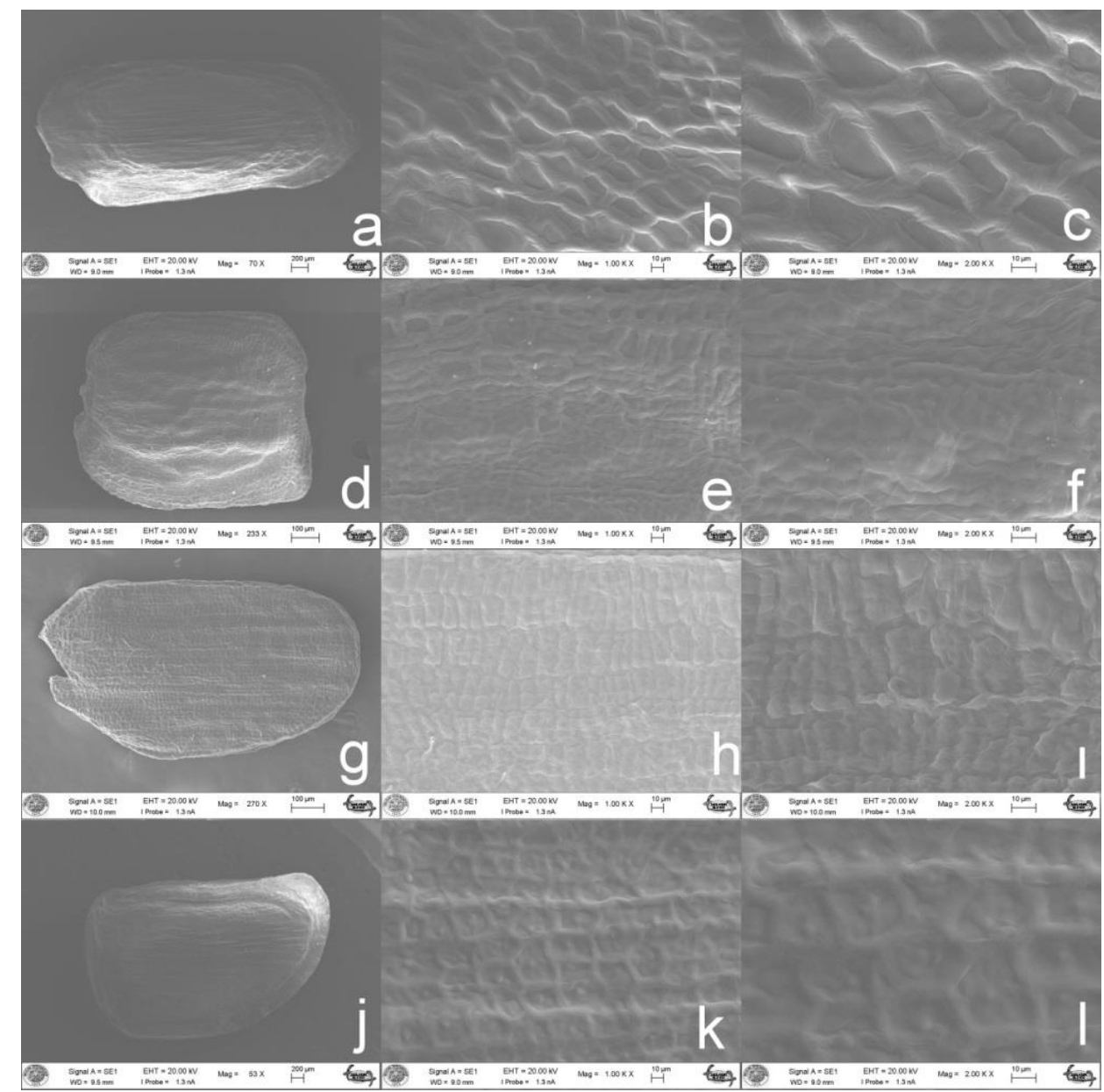

Figure 1. SEM micrographs of seeds of studied taxa: C. graeca $(\mathrm{a}-\mathrm{c})$, C. impatiens $(\mathrm{d}-\mathrm{f})$, C. raphanifolia $(\mathrm{g}-\mathrm{i})$ and $C$. uliginosa $(\mathrm{j}-1)$

The studied characteristics were not distinctive for Cardamine in genus level but especially seed coat ornamentation can be used as distinctive characteristics among the studied taxa. In future seed morphology studies about the rest of the Cardamine species will contribute to the interpretation of relationships of the taxa.

Table 2. Micro- and macromorphological seed features of studied taxa

\begin{tabular}{llllll}
\hline Taxa & Colour & Shape & $\begin{array}{l}\text { Length } \\
\text { (Mm) }\end{array}$ & $\begin{array}{l}\text { Width } \\
(\mathbf{M m})\end{array}$ & Ornamentation \\
\hline $\begin{array}{l}\text { Cardamine } \\
\text { graeca }\end{array}$ & $\begin{array}{l}\text { Dark brown } \\
\text { to black }\end{array}$ & Oblong & $4.61-4.82$ & $1.91-2.42$ & Regularly reticulate \\
C. impatiens & Brown & $\begin{array}{l}\text { Broadly } \\
\text { oblong }\end{array}$ & $1.11-1.02$ & $0.71-0.83$ & Irregularly reticulate \\
$\begin{array}{l}\text { C. raphanifolia } \\
\text { C. uliginosa }\end{array}$ & $\begin{array}{l}\text { Brown } \\
\text { Dark brown } \\
\text { to black }\end{array}$ & $\begin{array}{l}\text { Oblong } \\
\text { Broadly } \\
\text { oblong }\end{array}$ & $0.82-1.12$ & $0.42-0.71$ & Blister \\
& & & & $2.06-3.28$ & Tuberculate reticulate \\
\hline
\end{tabular}

Table 3. Comparison with previous studies

\begin{tabular}{lll}
\hline Studied Taxa & Results & Results Of Previous Studies \\
\hline Cardamine graeca & Regularly reticulate & Smooth [11] \\
C. impatiens & Irregularly reticulate & Smooth [11] \\
C. graeca & Oblong & Orbicular to oval [11] \\
C. impatiens & Broadly oblong & Oval [11] \\
\hline
\end{tabular}




\section{Acknowledgements}

The specimens were collected during the field trips for a project supported by a grant from Scientific Investigation Project Coordinator of Selçuk University (Project No: 15101001).

\section{References}

[1] Davis, P.H. (1965). Cruciferae. In: Davis P.H. (ed.) Flora of Turkey and the East Aegean Island. Edinburgh University Press, Edinburgh, Vol. 1, 248-495

[2] Davis, P.H., Mill, R.R. \& Tan, K. (1988). Cruciferae. In: Davis P.H. (ed.) Flora of Turkey and the East Aegean Island (supplement). Edinburgh University Press, Edinburgh, Vol. 10, 29-58, 232-235.

[3] Güner, A., Ozhatay, N., Ekim, T. \& Bafler K.H.C. (2000). Cruciferae. In: Davis P.H. (ed.) Flora of Turkey and the East Aegean Island. Edinburgh University Press, Edinburgh, Supplement 2, Vol. 11, 29-41.

[4] Al-Shehbaz, I.A., Mutlu, B. \& Dönmez, A.A. (2007). The Brassicaceae (Cruciferae) of Turkey, updated. Turkish Journal of Botany, 31(4), 327-336.

[5] Al-Shehbaz, I.A. (2015). Cardamine hongdeyuana (Brassicaceae), a new species from Xizang, China. Kew bulletin, 70(1), 3 .

[6] Al-Shehbaz, I.A. (2012). A generic and tribal synopsis of the Brassicaceae (Cruciferae). Taxon, 61, 931-954.

[7] Khatri, K. S. (1990). Cardamine L. sect. Macrophyllum Schulz, O.E. (Cruciferae Juss.) in the Asian Territory of the Soviet Union, A morphological, anatomical and phylogenetical study with taxonomic revision. Folia Geobotanica et Phytotaxonomica, 25(2), 197-215.

[8] Franzke, A., Pollmann, K., Bleeker, W., Kohrt, R., \& Hurka, H. (1998). Molecular systematics of Cardamine and allied genera (Brassicaceae): Its and non-coding chloroplast DNA. Folia Geobotanica, 33(3), 225-240.

[9] Heenan, P. B. (2017). A taxonomic revision of Cardamine L. (Brassicaceae) in New Zealand. Phytotaxa, 330(1), $1-154$.

[10] Mutlu, B. (2012). Cardamine L. In: Güner, A., Aslan, S., Ekim, T., Vural, M., Babaç, M.T. (editors). Türkiye Bitkileri Listesi (Damarlı Bitkiler). İstanbul, Turkey: Nezahat Gökyiğit Botanik Bahçesi ve Flora Araştırmaları Derneği, pp. 264-266 (in Turkish).

[11] Vaughan, J.G. \& Whitehouse, J.M. (1971). Seed structure and the taxonomy of the Cruciferae. Botanical Journal of Linnean Society, 64, 383-409.

[12] Barthlott, W. (1981). Epidermal and seed surface applicability and some evolutionary aspects. Nordic Journal of Botany, 1, 345-355. https://doi.org/10.1111/j.1756-1051.1981.tb00704.x

[13] Koul, K., Ranjna, N. \& Raina, S.N. (2000). Seed coat microsculpturing in Brassica and allied genera subtribes Brassicinae, Raphaninae, Moricandiinae). Annals of Botany, 86, 85-97. https://doi.org/10.1006/anbo.2000.1197

[14] Karaismailoğlu, M.C. (2019). The Value of the Seed in the Systematıc of the Family Brassicaceae. In: Research Reviews in Science and Mathematics-Summer, Editor: Sağlıker HA Gece Kitaplığı Yayınevi, New York, Ankara, pp. 51-80

[15] Stearn, W.T. (1992). Botanical Latin. David \& Charles Pub, London.

[16] Kasem, W.T., Ghareeb, A. \& Marwa, E. (2011). Seed Morphology and Seed Coat Sculpturing of 32 Taxa of Family Brassicaceae. Journal of American Science, 7(2), 166-178.

[17] Zeng, C.L., Wang, J.B., Liu, A.H. \& Wu, X.M. (2004). Seed coat microsculpturing changes during seed development in diploid and amphiploid Brassica Species. Annals of Botany, 93, 555-566. https://doi.org/10.1093/aob/mch080

[18] Murley, M.R. (1951). Seeds of the Cruciferae of northeastern North America. The American Midland Naturalist, 46, 1-81.

[19] Kaya, A., Ünal, M., Sefali, A., \& Martin, E. (2019). Fruit and seed macro-and micromorphologies of the genus Matthiola (Brassicaceae) in Turkey and their taxonomic value. Turkish Journal of Botany, 43(4), 516-528.

[20] Bona, M. (2013). Seed-coat microsculpturing of Turkish Lepidium (Brassicaceae) and its systematic application. Turkish Journal of Botany, 37, 662-668.

[21] Gabr, D.G. (2018). Significance of fruit and seed coat morphology in taxonomy and identification for some species of Brassicaceae. American Journal of Plant Sciences, 9, 380-402. 